\title{
From Committee to Controversy: An Actor-Network Analysis of the Re-Organization of the Norwegian CHM
}

\author{
Svein Vatsvag Nielsen \\ Department for Regional Development, East-Agder County Council, Arendal, Norway \\ Email: svein.v.nielsen@gmail.com \\ Received March $1^{\text {st }}, 2013$; revised April $1^{\text {st }}, 2013$; accepted May $19^{\text {th }}, 2013$
}

\begin{abstract}
Copyright (C) 2013 Svein Vatsvag Nielsen. This is an open access article distributed under the Creative Commons Attribution License, which permits unrestricted use, distribution, and reproduction in any medium, provided the original work is properly cited.
\end{abstract}

\begin{abstract}
Starting in 1986 and ending in 2001, the Norwegian cultural heritage management (CHM) underwent a re-organization. Following the revised Heritage Act of 1978 the protective devise needed revision. The 19 County Councils received increased authority after the Act in 1990, while the five archaeological government museums decreased their authority, and were set to focus solely on traditional cultural historic research. The restructuring changed the expert knowledge systems (i.e. institutionalized scientific knowledge) integrated in the CHM, and the process was met with suspicion in the academic community. By conducting a close reading of two central governance policy documents from the 1980's, the re-organization is analyzed in accordance with the methodology of ANT. It is argued that as the re-organization can be considered a success with respect to its political goals, it was nonetheless also a destructive event. The relational effects of the re-organization are then analyzed in relation to Bruno Latour's theory of political ecology. Here it is argued that the democratizing and distributional effects on the involved sciences (i.e. archaeology) can be read as an "ecologizing" event, and eventually, that the academic controversy is further proof of this. In the end, the author argues for the potential of CHM studies to enrich the larger discourse on modernity and the political practice of modernizing.
\end{abstract}

Keywords: Organization; History; Archaeology; Political Ecology; Modernity; CHM; ANT

\section{Introduction}

" Ecologising' means creating the procedures that make it possible to follow a network of quasi-objects whose relations of subordinates remain uncertain and which thus require a new form of political activity adapted to follow them" (Latour, 1998: p. 22).

Why not start with a year. It was 1979 and the chosen thirteen had gathered in Oslo for the first time. They were all representatives from central institutions involved in the Norwegian Cultural Heritage Management (CHM), including the five archaeological government museums, the Directorate for Cultural Heritage, the Ministry of the Environment, the Norwegian Federation of Municipalities, the rationing Affair-in short, key politicians and prominent experts on the field. They had been appointed by the Government to examine the basis for a new organization of the Norwegian CHM. The group was well known in political and academic circles, where they simply went under the name "the organization committee".

In the years prior to the establishment of the committee, it had become increasingly clear that the State's protective device had failed to prepare for the responsibilities that were to follow the new Heritage Act of 1978. The loss of prehistoric monuments was increasing, and the system simply did not function anymore. The Norwegian CHM had to be re-organized.

In the course of the next four years the committee held a total of 24 meetings, resulting finally in a thick Official Norwegian Report (NOU, 1982: p. 36). The core point was simple; from a "distinctly offensive position" the Norwegian CHM were to develop an "aggressive approach with a targeted, long-term protection policy" (NOU, 1982: p. 36, authors translation). Norway had recently gained a new Heritage Act - perhaps the strictest in the world (Myklebust, 2002), and now the government agencies had to adapt. The final decision on the future organization of the Norwegian cultural heritage was later enshrined in an official White Paper in 1986 (MOTE, 1986).

What kind of documents are these, and what happened in them? In this article, which is a processing of a previously prepared thesis (Nielsen, 2011), the overall theme is what governance policy documents do. This theme will be illustrated through a close reading of the two aforementioned governance policy documents from the early phase of the re-organization of the Norwegian CHM. The reading will involve analytical aspects from actor-network theory (ANT) and science-studies (Latour, 1993, 2005; Callon, 2001; Asdal, 2008b, 2011b).

\section{Political Documents as Information and Actor}

As with all text, governance policy documents convey meaning through opinions and speech acts; they store and transmit information from source to reader. In this way, the report from 1982 presents the case made by "the organization committee", while the White Paper from 1986 lays forth the case made by the Government. However, in addition to being a strict means of communication, the documents are also part of 
physical reality; they have their own materiality. According to ANT, a focus on the materiality of things can help demonstrating that documents not only inform, but that in specific social situations, they can become active, mediating parts in social life (Latour, 2005). The documents can in a sense become the case (Asdal, 2011b).

As the documents were published in the 1980's, narrowing an analysis of state affairs to a certain decade is nonetheless problematic. The report from 1982 and the White Paper from 1986 were only the first steps in a process that ended in 2001 (NOU, 2002). According to the state's own historiog- raphy, the case was originally made by the White Paper (Niel- sen, 2011).

So what kind of text is this? When the Government or a ministry has the need to investigate different conditions in Norwegian society, they set up a committee to produce a report on the case (i.e. Norwegian Official Report). These reports are intended to create and maintain a vibrant democracy, and a government report may in some cases lead to a larger political process resulting in a White Paper. This was the case with NOU (1982: p. 36) and White Paper No. 39. While the report presented views, arguments and votes from a group of experts, bureaucrats and politicians, the White Paper presented the Government's own position in the case.

Why highlight precisely these texts? As mentioned earlier, the White Paper came to play a central mediating role in the post-war history of Norwegian CHM. According to later documents, the foundation for further development was laid here (Nielsen, 2011). In accordance with ANT, where focus lays on the actors, an analysis of recent development in the Norwegian CHM must take into account the role of the White Paper. However, as the conditions of the White Paper are to be found in the earlier report, it follows that the two texts must be read in close relation to one another.

But there is also another reason to pay close attention to the documents. The practice of government, in the sense of Foucaults' gouvernementalité, implies a use of specific technologies in order to incorporate scientific knowledge into the political field. The Norwegian Official Report and the process of translation it becomes part of, can be considered one of these political technologies (Asdal, 2011b).

\section{Writing History (with-) in Politics}

The post-war period in Norway is often divided into different eras: the reconstruction, the golden 60 's, and the "green wave" in the 70's (Lange, 1997; Asdal, 2011b). The politics of the 1980 's and the so-called "modernization of government" in the 90's are often analyzed in light of Neoliberal political influence and the effects of New Public Management (NPM) (Øgard, 2003; Trygstad, 2004; Baldersheim \& Rose, 2005; Brattli, 2006; Hernes, 2007). Unlike various parts of the public sector, Norwegian CHM was never privatized, and according to political discourse privatization was never an alternative (Nielsen, 2011). In 2013, the organizational pattern follows a centralized distribution of power where the Directorate for Cultural Heritage functions as the link between the Ministry and the regional actors. Both the archaeological government museums and the countries 19 County Councils have authority regulated in the Heritage Act. The County Councils are responsible for registration of prehistoric monuments in areas where development initiatives are engaged, while the museums excavate the sites, a practice partly shared with NIKU (The Norwegian Institute for Cultural Heritage Research).

The current system of CHM is a direct result of the process initiated by NOU (1982: p. 36). But the State has not only played a central part in the development of management; intervention has also been made in the field of cultural heritage research. In the late 1980's, and as part of the re-organization, the Ministry of the Environment created a distinction between two types of heritage research. On the one hand was the cultural historic (i.e. traditional archaeological research), and on the other cultural heritage research (i.e. research on management and politics) (Marstein, 1991; MOTE, 1993). The need for an external institution with the prime responsibility for R \& D activities and cultural heritage research became one of the key reasons for the creation of NIKU in 1994.

This digression from the main case is done merely to point out how re-organizations are more than solutions to supposedly technical problems. The re-organization of the Norwegian $\mathrm{CHM}$ even changed the very definition of archaeological activities in general. By following associations in the State's own documents, it is possible to demonstrate how the State itself is not limited to one definite location. On the contrary; through a combination of naming objects and creating technologies in order to govern them, new areas of State intervention are developed (Asdal, 2008b).

\section{The Practice of Texts}

Within the field of interdisciplinary cultural research, the application of ANT in environmental history has been termed a "practical approach" (Asdal, 2008b, 2011b). Political science has traditionally treated policy documents as the state's official communication (Svardal, 1992). Publication of documents is meant to create and maintain a transparent society where all members have access to political decision making. However, these texts have also a technical side to them. In practice, they are engaged in social networks where they-in addition to being a means of communication, act as full blown mediators in policy making. The White Paper is an example of such a mediator in Norwegian politics; its role is to create policy, and as such it is a political act in itself. With the White Paper, presentation and re-presentation merge.

But the constructive relationship between people and things work both ways. As objects determine our practice, our practice determines the objects in the first place (Asdal, 2008b). With the White Paper, a mandatory passage point is made, an actor that no one can avoid dealing with when dealing with the case (Latour, 1993; Brattli, 2006). When White Paper No. 39 was published it declared that a re-organization was on its way, and in that moment, the document was the re-organization.

What policy documents actually do is rarely asked within cultural heritage research (but see Brattli, 2006). In Norway this research is of fairly new date (Christensen, 2011: p. 14). On the field of building protection, Hans Emil Lidén (Liden, 1992) has still the only historical work (Christensen, 2011), while major contributions on the protection of prehistoric monuments still remains few in numbers (Trøim, 1992; Hygen, 1996; Brattli, 2006; Glørstad \& Kallhovd, 2011). The field is characterized by discursive divisions following disciplinary boarders; as archae ologists have maintained a focus on prehistoric (automatically protected) monuments, art historians have in turn covered the history relating to standing buildings and modernity 
(Hegardt, 1984; Christensen, 2011). In short, there seems to be a discipline still short of discipline.

For several years now, science studies have made its definite influence on the field of environmental history in Norway (Asdal, 2003, 2008a, 2011a, 2011b). This research program is based on the tradition following Michel Foucault and the actor-network theory of Bruno Latour where the prime goal is to study environmental history as a continuous interaction of people and things. Here, the status of actor can be associated with all creatures, while the social is reserved merely for that which binds the actors together (Latour, 2005). This allows for the sociological study of what Latour has termed "the parliament of things", or as Foucault put it; "the complex of people and things" (Foucault, 2002).

Latour famously stated in the Irreduction part of The Pasteurizatin of France that nothing can be reduced to anything other than itself (Latour, 1988). This means that in the study of an object, an actor, or a case, that plays a role in a process of translation, we cannot jump so easily from one social setting to another without having accounted for potential transformations that occurred along the way. Information is transformation, Latour writes (Latour, 2005). In this way, ANT as an analytical tool is an argument for description as well as reluctance to explanation. The task of sociology is to provide a rigorous account of the specific situation, of the case.

\section{9}

What was the case in 1979, when "the organization committee" was formed? According to different versions of Norwegian history, heritage protection was not part of the "green wave" in 1970 's, nor of the environmental movement of the 80's (Lange, 1997; Furre, 1999). The political environmental case was reserved for Nature, and so was the social movement concerned for protecting it. Effectively, past conservation never received the attention of environmentalism.

It should be added that cultural heritage protection has traditionally been - and still is, associated with the cultural sphere of Norwegian society and politics. The ecological activism of the 70's equaled with major changes in the Norwegian cultural policy. Deeply inspired by the new French cultural policy of the 1960 's, the old distinction between "high" and "low" culture were now to be exceeded (Keller, 2006). Culture should be enjoyable for all social strata, not just the upper class. The practical result was a clear focus on decentralization of political decision making to the County Councils. Whether this regionalization made any impact on the Norwegian CHM, the history books avoid mentioning it (Lange, 1997; Benum, 1998).

To gain insight into the state of Norwegian CHM in 1979, we must pay attention to the policy documents from the period. In this respect, the work done by "the organization committee" becomes a vital source of information. According to their report, a general conflict between development and conservation reigned in Norwegian society. The conflict had its origin in the post-war era and had been growing consistently ever since, while an additional deterioration had occurred with the new cultural policy of the 1970's; after the new Heritage act from 1978 cultural heritage was defined as all traces (sic) of human activity. All monuments predating the Reformation (1537), known or unknown, were now subject to automatic protection, and as such, they had to be managed.

The condition of the system in 1979 was thus characterized by a long-term problem. Now the Heritage Act had parted the management in two. On the one hand, the State was required to carry out registration of monuments in the context of rezoning and development initiatives. And on the other, if the area in question was to be exploited, the monuments had to be excavated and conserved in a proper, scientific manner. Both tasks belonged to the Ministry of the Environment, but the roles and authorities in the practical administration were unclear. The agencies needed structure and efficiency. However, this was not a public issue, and the re-organization became a purely internal affair. It remained a clear case for an expert committee.

\section{The Experts}

By including experts from a specific scientific field in political committees, these actors get to play a vital role in policy making. Among the expert members of "the organization committee" were Stephan Tschudi-Madsen and Odmund Møllerup. Tschudi-Madsen, an art historian by education, was head of The Directorate for Cultural Heritage. Odmund Møllerup on the other hand was a prominent archaeologist and director of one of the five archaeological government museums. He had previously been a key player in the committee behind the revised Heritage Act (Trøim, 1992).

Still the majority of the members were representatives of political institutions, including the Ministry of the Environment, the county and the municipality. The committee's chairman, Yngvar Johnsen, was a representative of the Ministry, as was the member Astrid Bonesmo. Bonesmo was an architect by education and had her background as bureau chief in the Ministry.

Into what political, social or scientific setting was the committee to inscribe their case? "There is an increasing pressure on cultural heritage from development interests, while there seems to be a growing interest in and appreciation for preserving precious memories about past life and culture" (NOU, 1982: p. 36). This is stated in the introduction of the report as an excerpt from the resolution that had originally appointed the committee. By linking the cultural heritage to both environmental and cultural policies the case gained great political significance, but as this was stated in the resolution, the Ministry had already defined the case. The limits were set.

The main task of the committee was to report and vote on future organization patterns for the district apparatus. The responsibility for registration of monuments entailed keeping procedures with local authorities and developers. Should a separate agency be in charge of this, or should both registration and excavation be collected in a single unit? Polls showed that the expert knowledge stood strong; the majority of the committee voted for placing all authority at the five archaeological government museums. According to the majority, it was "important that management decisions have their basis in science".

But the proposal did not go unchallenged. In what was termed a "special statement", the member Bonesmo voted single-handedly for placing the registration practice at the County Councils. This was justified because the model proposed by the majority went against "common management practice" and "the normal levels of state, county and municipality". According to this member, it was only matter of time until authority would be transferred to the County Councils.

It is obvious that the committee was split between different interests. On the one side were defenders of the old organiza- 
tion structure, where expert institutions maintained authority. On the other was the Ministry defending the new policy with its focus on decentralization. The conflict became crystallized when the case of ministry linking was voted on. Though this was not part of the original mandate, the majority saw this as essential for an alternative future organization of the CHM. Shockingly, the vote resulted in a majority to move the CHM from the Ministry of the Environment to the Ministry of Culture and Science, where it originally had been located in forefront of the establishment of the Ministry of the Environment in 1972. In a quite literal sense, the majority associated CHM with culture and cultural work, not with nature and environmental protection.

\section{The Politics}

Reading the report from 1982 we are witnessing a committee taking a stand against the major policies of the time. The majority wanted to strengthen the position of the scientific institutions and the traditional know-how gathered there, effectively demonstrating a direct antipathy to both cultural policy (i.e. decentralization of political decision making) and environmental policy (i.e. decisions grounded in science, not development interests). The White Paper from 1986 was prepared by the Ministry of the Environment, and through this the government made its decision in the case.

What happens in and with the White Paper? Compared to the report, this document differs in both form and content. The White Paper is much shorter and decisions are declared through performative statements. The ministry link, which "the organization committee" had insisted on voting on, was not mentioned by the Government. Regarding the district apparatus, it was stated that the only real candidate were the County Councils. Giving authority for both registration and excavation of monuments to the archaeological government museums would not fulfill "the objectives of a single and unified management model". On the contrary, the museums were to be "excused" for purely administrative tasks, and should only be concerned with traditional cultural historic research and scientific excavations of endangered monuments.

The White Paper did not take into account the majority votes in the older report. On the contrary, to justify its decisions the document referred directly to the "special statement" made by Bonesmo, but without mentioning that this member was herself a bureau chief from the Ministry. Furthermore, we are informed that a trial period with the County Council model had already been implemented in 1983.

As already mentioned, the White Paper can be read as a pivotal point for post-war CHM in Norway. This document marked the announcement of major changes to come, the first being deployed in 1989 through a new regulation of the Heritage Act (MOTE, 1989). This is also confirmed by the State's own historiography, where the White Paper is recognized as the foundation of todays "modernized" CHM (NOU, 2002).

\section{Controversy as Translation}

How should we understand the process accounted for above? According to Michael Callon (Callon, 2001) a process of translation consists of four different stages. The first stage is recognized as a phase of questioning, where the actors involved attempts to define the roles and identities of the others. The questioning is followed by an interesting, wherein the winning party attempts to stabilize the new order of things. At the stage of interesting, the modus operandi among the actors is anything goes (Callon, 2001: p. 102).

Can the early phase of the re-organization be read as a scientific controversy? By cutting the literary ties to the earlier report, the Ministry succeeded in stabilizing the vision of the County Council as district apparatus, a model it had itself proposed in the first place through a "special statement". By re-producing the same history repeatedly in subsequent documents, it managed to maintain its own interesting. A striking example of this occurs in the Ministry's action plan from 1992. While accounting for the history of the Norwegian CHM it is explicitly stated that in respect to the political purpose of the action plan, the report from 1982 had been subject to strict censorship (Nielsen, 2011).

But what about the scientific interests invested in "the organization committee"? It is a historical fact that that the origins of the institutionalized protection of prehistoric monuments are linked directly to persons with scientific interests, and that the guard has since been sustained by institutions sharing similar interests (Shetelig, 1944; Glørstad \& Kallhovd, 2011). The Ministry of the Environment took issue with this tradition in the White Paper by stating that “... it is in line with current cultural policy a national responsibility to protect cultural heritage. However, there is generally no national interest associated with removing them. For protection authorities and scientific interests, it is desirable that the source material remains intact in its natural context" (MOTE, 1986: p. 19). By allowing itself to speak on behalf of all the parties involved, including the sciences, the Ministry could convince all readers that there was no internal controversy. Apparently, both politicians and scientists were unanimous in the case.

According to the model proposed by Callon (2001), a successful interesting is followed by an enrollment, a phase of theoretical planning. This institution building propagates physically at the moment the mobilization takes place (Brattli, 2006: pp. 45-46). Following this, the new regulation of the Heritage Act in 1989 can be read as an enrollment, while the practical changes occurring the following year marked the final mobilization.

\section{The Role of Free Association}

While the original resolution effectively reduced the problem to a purely technical matter-as long as the right actors were placed into the right order it was thought that the problem would vanish, the reading of NOU (1982: p. 36) and White Paper No. 39 showed that the changes would cause dire consequences. The documents testified to a deeper issue; that the various actors in the administrative apparatus ware not collected.

As the split was evident in the report, it was subsequently brought to discussion in the Recommendation to the White Paper in $1987^{1}$. According to the White Paper, the archaeological government museums were to be put into a position enabling them to pursue their research interests. As for their role in the CHM, they were only to carry out excavations on the order of the authorities. However, from academic hold such a distinc-

\footnotetext{
${ }^{1}$ The source here is Recommendation S.135 (1987-1988) by the Parliament Municipal and Environmental Protection Committee. Through Recommendations, the political parties highlight their position in a case put forward by the government.
} 
tion was seen as "very problematic". In the Recommendation, it was also pointed out that the Ministry of the Environment had in fact ignored the earlier majority vote against the County Council model, and had effectively acted against the vibrant democracy.

This attempt at questioning in the Recommendation was nonetheless unsuccessful. How did the Ministry get approval of their politics? Here we need to take a step back in the above story, and go outside the network of associations the State itself conveyed. This analytical "going outside" is what Callon has termed free association (Callon, 2001).

One missing document in the process is an older report called NOU (1977: p. 50). Published by the Ministry of the Environment, there is no mentioning of this text in the whole process of the re-organization (but see Hygen, 1996).

The committee behind NOU (1977: p. 50) had been appointed by the Ministry, but as the report was not meant to lead to a political process it served solely an internal purpose. Its chairman was Astrid Bonesmo, later to be recognized as part of "the organization committee" and the one member who was cited in White Paper No. 39 favoring the County Council model. The primary task of NOU (1977: p. 50) was to report on the possible impacts of the new Heritage Act once it had been implemented, with a special focus on future organizational changes. As the committee agreed that authority eventually had to be transferred to the County Councils, this report demonstrates how the organizational model had in fact circulated within the Ministry for over a decade before the publication of the White Paper in 1986.

\section{A Growing Controversy}

It becomes clear then, that this decisive period of post-war CHM in Norway was in fact characterized by more than an increasing loss of monuments. It is significant that up until the revised Heritage Act of 1978, systemic problems had been taking care of solely by internal commissions, all of which were products of expert knowledge systems (i.e. archaeologists and their institutions) used to handling problems in their own fashion (Trøim, 1992). The re-organization shook this old network, and thus the re-organization was not purely a solution; it was also a destructive act.

Of this controversial process several different readings are possible. According to art historian Arne Lie Christensen, the transmission of the CHM to the Ministry of the Environment in 1973 happened originally as a result of the "new thinking" in Norwegian environmental policy (Christensen, 2011: p. 137). Further, when the County Councils were later to be mobilized, it was only because this vision "won" (Ibid). Evidently, interpreting political history as a continuing flow of change and effectively avoiding mentioning internal controversies is possible. But is this a reading that takes into account the particular by the case itself, or even acknowledges the case as such?

To presuppose a social substance that has the potential to exp lain everything is, following Latour, the greatest fault in sociology (Latour, 2005: p. 144). Through practical examples, science studies have demonstrated how history is not linear, but rather full of uncertainty and controversy (Shapin \& Schaffer, 1985). Following this field, a close reading of the central government policy documents from the re-organization of the Norwegian CHM could show that this was exactly the case. From an academic hold, the deprival of authority from ar- chaeological government museums in 1990 has been interpreted as an historic milestone for the bureaucratic powers that affect Norwegian archaeology, transforming the CHM into a political field (Boaz, 1998; Keller, 1999). Consequently, central in the academic discourse has been a hermeneutic of suspicion aiming at identifying the suspects (Nielsen, 2011).

In light of this discourse, the White Paper from 1986 can be read as a turning point not only for the CHM, but also for the field of archaeology in Norway. One could say that the re-organization changed archaeology's most basic conditions for production (Keller, 2006).

The academic community became critical to the development that started with "the organization committee". But was the criticism unjustified? Within political science, the 1970's are often characterized by the Labor Party losing its post-war dominant position (Pettersen, 2009). Significantly, this rupture is tangent with two phenomena; the increasing use of public committees in policy making, and the final breakthrough for lobbying within Norwegian politics (Pettersen, 2009, with reference to Espeli, 1999: p. 169). The reading of the central documents from the re-organization of the CHM is consistent with this panorama; the organizational model was planned by the Ministry of the Environment and all subsequent disagreements were discarded. It was even possible to identify central actors in the process.

However, while it remains significant that the scientific expert systems failed in their attempt at defining the case, should this historical fact in itself be considered controversial? Through case studies, science studies have demonstrated that this is more the rule then the exception. As it happens, scientific knowledge quite often do not determine policy making (Asdal, 2011b: p. 237). While scientific knowledge is often involved through representatives in committees, there is always a process of translation. As this analysis could show, the basis for the re-organization was visions and ideas, not scientific knowledge.

\section{Political Ecology and CHM}

Within ANT and the discourse on modernity, Latour highlyghts political ecology as the only real alternative to modernization (Latour, 1998, 1993, 2004). His analysis points out that ecology, as far as being a political rationale, has effectively been reserved as a normalizing project (Latour, 1998). Just as the 19th century never saw a "hygienist party", there will never be a "cultural heritage party" in 21st century. Following Richard Bradley's take on British CHM, the reason for this is simple; cultural heritage is not attractive for real-politik (Bradley, 2006), and when there is no voting, there will be no new policy.

Later policy documents from the 1990's show that the re-organization of the Norwegian CHM eventually came to be understood as part of the larger government project called "modernization of public sector" (Nielsen, 2011). Restructuring became a key technology in this project, and it is estimated that in the period of 1985-1995, more than 900 re-organizations were mentioned in state budgets (Riksrevisjonen, 2005). And the trend only increased the following decayed. Again, the Ministry's identification of the re-organization with the "modernization" project must be read as part of a continuing interesting. By increasing the associations connected to the re-organization, the phenomenon in itself became bigger, more social -more real. Though the origin of the process was found to be in the 1970's, according to the State's own historiography the 
re-organization became increasingly understood as a footnote to the major government restructuring of the 90's. As such, the re-organization can be associated with the early phase of NPM influence in the Norwegian public sector, but as the analysis here have shown, in anything the influence was nothing but skin.

Down to this point, this analysis has demonstrated how the re-organization of the Norwegian CHM has been considered an adverse event - even a symptom of a larger destructive process. But can we make yet another reading here? Following the re-organization, it has been said that Norway's protective system is among the strictest and most successful (Myklebust, 2002). The old problems have been resolved, and as such, the re-organization can also be read as a constructive process. Something was made through the re-organization. How can this be related to Latour's take on political ecology? In his book Politics of Nature (Latour, 2004), Latour notes the following:

"It was thought that political ecology had to bring humans and non-humans together, whereas it actually had to bring together the scientific and the political ways of intermingling humans and nonhumans. There is indeed a division of labor, but there is not a division of the collective" (Latour, 2004: p. 148).

A bringing together of scientific and political practice-is this not exactly what the above analysis could demonstrate happened to the Norwegian CHM in the period from 1979 to 2001? In a quite literal sense, the re-organization moved the monuments-i.e. the non-human social actors, away from the expert institutions and into the local democracy of the County Councils. Connections were cut, new was made. The monuments became an integral part of land use planning in the municipalities, and of society, in a whole new way. And this happened not in spite of expert knowledge; following the regulation of the Heritage Act in 1989, archaeologists were now distributed to counties across the country, increasing the degree of intermingling.

According to Latour, political ecology as realpolitik imposes a re-organization of the sciences involved in political policy making. Science should be democratized, not hidden away in expert knowledge systems. Latour's definition of political ecology must of course be read as a part of his work within the discourse on ANT. It is therefore significant that only an analysis in accordance with this can successfully capture the different forms "ecologizing" can take in practical policy making. Perhaps the growing academic controversy tangent with the re-organization can be read not as sign of its failure but, on the contrary, as an argument for its success?

\section{Conclusion}

As the environmental historian Kristin Asdal writes, governance documents are linked to a political machinery that helps the texts to reach far and wide (Asdal, 2008b). This article has made an attempt at demonstrating how a "practical approach" can enlighten the relation between science and politics in CHM through studies of organizational change. A close reading of these mediating texts can demonstrate how they enact out, how they both inform and transform the specific case. Taking these documents seriously can lead to the creation of new and unknown histories.

In contrast to earlier interpretations, it has been argued here that uncertainty and controversy played a major role in re-organizing the Norwegian CHM in the 1980- and 90's. I have pointed out that the process was both constructive and destructive; destructive because it dramatically changed the nature of the scientific expert systems, and constructive because it led to the functional and aggressive system that was originally intended in 1979. It has also been argued that the democratization and regionalization of authority to the County Councils in 1990 was an event corresponding positively with Latours' theory of "ecologizing" politics. Regionalization brought the representatives of protected things closer to local political decision making, distributing the uncertainty and caution associated with prehistoric monuments as far as possible. One could say that the Norwegian CHM went one step further into becoming "a collective experimentation on the possible association between things and people" (Latour, 1998: p. 21).

It must be mentioned that the core point in Latour's theory of modernity rests on the now infamous premise that "we have never been modern" (Latour, 1993). By deploying a specific practice of translation - sorting things in accordance with a nature-culture duality, we have told ourselves that we are modern. Latour's solution is in this respect simple; we must start by sorting things differently. But how could past conservation ever fit into this rationale in the first place? If anything, prehistoric monuments in themselves embody the modernist duality of nature and culture, and as such, they remain a potential anomaly in the rationale. It is precisely here, in this conceptual abyss, that studies of CHM have the great potential to demonstrate how modernity has sought to cope with its anomalies.

\section{REFERENCES}

Asdal, K. (2003). The problematic nature of nature: The post-constructivist challenge to environmental history. History and Theory, 42, 6074.

Asdal, K. (2008a). Enacting things through numbers: Taking nature into accounting. Geoforum, 39, 123-132.

doi:10.1016/j.geoforum.2006.11.004

Asdal, K. (2008b). Å lese tekst og miljøhistorie. Fortid, 4, 37-40.

Asdal, K. (2011a). On politics and the little tools of democracy: A down-to-earth approach. Distinktion: Scandinavian Journal of Social Teory, 9, 37-41.

Asdal, K. (2011b). Politikkens natur-naturens politikk. Oslo: Universitetsforlaget.

Baldersheim, H., \& Rose, L. E. (2005). Det kommunale laboratorium. Teoretiske perspektiver på lokal politikk og organisering, Fagbokforlaget.

Benum, E. (1998). Norges historie bind 12 K.. Oslo: Aschehougs.

Boaz, J. (1998). Forskning og forvaltning: En diskusjon om forvaltningens fremtid. Primitive Tider, 1.

Bradley, R. (2006). Bridging the two cultures. Commercial archaeology and the study of Prehistoric Britain. Antiquaries Journal, 86, 1-13.

Brattli, T. (2006). Fortid og forvaltning. En analyse av norsk kulturminneforvaltning i perioden 1990-2005, med hovedvekt på arkeologisk forhold. Trondheim: NTNU.

Callon, M. (2001). Elementer til en oversettelsessosiologi. In I. Moser (Ed.), Teknovitenskapelige kulturer. Oslo: Spartacus.

Christensen, A. L. (2011). Kunsten å bevare. Om kulturminnevern og fortidsinteresse i Norge. Pax Forlag.

Foucault, M. (2002). Forelesninger om Regjering og Styringskunst. Oslo: Cappelen Akademisk Forlag.

Furre, B. (1999). Norsk historie 1914-2000, Oslo: Det Norske Samlaget.

Glørstad, H., \& Kallhovd, K. (2011). Rescue archaeology initiated by research-A contradiction in terms? In G. Blancquaert et al. (Eds.), 


\section{S. V. NIELSEN}

Understanding the past: A matter of surface-area (pp. 113-127). Archaeo Press.

Hegardt, T. (1984). Romantikk og fortidsvern. Historien om de første friluftsmuseene i Norge. Oslo: Universitetsforlaget.

Hernes, G. (2007). Med på laget. Om New Public Management og sosial kapital i den norske modellen. Fafo-Rapport 2007:09.

Hygen, A. S. (1996). Fornminnevern og forvaltning. En teoretisk og metodisk tilncerm til planlegging og praksis $i$ kulturminnevernet. Oslo: NIKU Temahefte 1.

Keller, C. (1999). Forskning og forvaltning. Primitive Tider.

Keller, C. (2006). 80-årenes arkeologi-Fra Norsk Løve til Fransk Puddel. Nikolay, 100, 17-23.

Lange, E. (1997). Norges historie bind 11. Oslo: Aschehougs.

Latour, B. (1988). The pasteurization of France. Harvard: Harvard University Press.

Latour, B. (1993). We have never been modern. Harvard: Harvard University Press.

Latour, B. (1998). To modernize or to ecologize? That's the question. In N. Castree, \& B. Willems-Braun, (Eds). Remaking reality: Nature at the millenium (pp. 221-242). London and New York: Routledge.

Latour, B. (2004). Politics of nature. How to bring the sciences into democracy. Harvard: Harvard University Press.

Latour, B. (2005). Re-assembling the social. An introduction to actor-network-theory. Oxford: Oxford University Press.

Liden, H. E. (1992). Fra antikvitet til kulturminne. Trekk fra kulturminnevernets historie i norge. Universitetsforlaget.

Marstein, N. (1991). Presentasjon av FOK-programmet. In Bygningshistorie og bygningsvern. Rapport fra seminar 14-16-mars 1990, Solstrand Fjord Hotel. NAVF.

MOTE (1986). St.meld. Nr. 39 (1986-87) Bygnings og fornminnevernet Miljøverndepartementet, ed., Oslo.

MOTE (1989). T6/89. Delegasjon. Nye forskrifter til kulturminneloven om faglig ansvarfordeling mv. delegasjon, Oslo: Miljøverndepartementet.

MOTE (1993). T-951. Organisering av forsknings-og utredningsvirk- somheten innen kulturminnevernet. Rapport utarbeidet av en interdepartemental arbeidsgruppe, Oslo.

Myklebust, D. (2002). Kulturminnevernets begrunnelse-En pest eller rett og slett en plage. NIKU Tema 5. Oslo.

Nielsen, S. V. (2011). Fra komité til kontrovers. Kritiske passasjer fra omorganiseringen av norsk kulturminneforvaltning. NTNU.

NOU (1977). Offentlig kulturvern på fylkesnivå. Miljøverndepartementet.

NOU (1982). Kulturminnevernet. Organisasjonsspørsmål innenfor kulturminnevernet i Norge. Oslo: Universitetsforlaget.

NOU (2002). Fortid former fremtid. Oslo: Universitetsforlaget.

Øgård, M. (2003). Is local democracy under pressure from new public management? In H. Baldersheim, \& J. P. Daloz (Eds.), Political leadership in a global age: The experiences of France and Norway. Ashgate. Pettersen, K. B. (2009). Norske Organisasjoner og Stortinget. Lobbyvirksomhet og åpne høringer, Oslo: Masteroppgave ved Institutt for Statsvitenskap.

Riksrevisjonen (2005). Dokument 3:11 (2004-2005). Riksrevisjonens undersøkelse av omorganiseringer som forvaltningspolitisk virkemiddel, Oslo.

Shapin, S., \& Schaffer, S. (1985). Leviathan and the air-pump. Hobbes, boyle and the experimental life. Princeton.

Shetelig, H. (1944). Foreningen til Norske Fortidsminnesmerkers Bevaring 1844-1944. Viking. Tidsskrift for norrøn arkeologi. Bind, 7, 7-14.

Svardal, G. (1992). Stortinget, regjeringen og statsadministrasjonen. In T. Christensen, \& M. Egeberg (Eds.), Forvaltningskunnskap. Forvaltning i samfunnet: Tano.

Trøim, I. (1992). Arkeologisk forskning og det lovregulerte fornminnevernet. En studie av fornminnevernets utvikling i perioden 1905-1978, Universitetet i Oslo.

Trygstad, S. C. (2004). Fra rettighet til nytte? Det kommunale bedriftsdemokratiet møter New Public Management, Dr. polit-avhandling. Institutt for sosiologi og statsvitenskap. NTNU. 